\title{
ANALISIS KAWASAN MINAPOLITAN SEBAGAI DESTINASI WISATA
}

\author{
Liliana Dewi ${ }^{1}$, Putu Swasti Asparini ${ }^{2}$ \\ ${ }^{1}$ Sekolah Tinggi Pariwisata Bogor, lilidewi.ana@gmail.com \\ ${ }^{2}$ Sekolah Tinggi Pariwisata Bogor, putuswastiasparini@gmail.com
}

\begin{abstract}
ABSTRAK:
Kawasan Minapolitan berada di tiga kecamatan, yaitu Kecamatan Ciseeng, Parung, Gunung Sindur, dan Kemang dengan 14 daya tarik wisata. Berdasarkan hasil analisis, diketahui bahwa Kawasan Minapolitan memiliki potensi yang bisa dikembangkan melalui diferensiasi produk dan kegiatan wisata diharapkan dapat menarik minat wisatawan untuk berkunjung. Didukung dengan sumber daya manusia yang terampil dan aksesibilitas yang memadai. Diketahui juga dari hasil analisis di lapangan, terbuka luas kesempatan berusaha di industri pariwisata khususnya Kawasan Minapolitan baik dari segi daya tarik wisata, kawasan pariwisata, jasa transportasi wisata, jasa makanan dan minuman, penyediaan akomodasi, penyediaan kegiatan hiburan dan rekreasi, jasa informasi wisata, hingga wisata tirta.
\end{abstract}

Kata Kunci: minapolitan, destinasi wisata, pariwisata, daya tarik wisata, industri pariwisata

\section{PENDAHULUAN}

Salah satu sektor peningkatan perekonomian adalah pembangunan pada bidang pariwisata. Sektor pariwisata merupakan salah satu sektor penting sumber devisa negara dan sebagai sumber pendapatan daerah.

Kabupaten Bogor memiliki keindahan alam, seperti Riung Gunung, Tambang Emas Pongkor, Taman Safari Indonesia, Taman Sri Bagenda, Sumber Mata Air Jalatunda, Taman Buah Mekar Sari, Telaga Warna, ataupun wisata pendidikan seperti Wisata Pendidikan Bodogol, Hutan Wisata Catang Malang, Danau Lido, Taman KupuKupu, Curug Cilember, Gunung Salak, Curug Dengdeng (Kecamatan Rumpin), Curug Cigamea, Curug Seribu, Kawah Ratu, Bumi Perkemahanan Gunung Bunder, Curug Ngumpet (Kecamatan Pamijahan), Gua Gundawang (kecamatan Cigudeg), Wanawisata Gunung Pancar (Kecamatan Babakan Madang), Curug Luhur, Curug Titis (Kecamatan Ciomas), Curug Nangka (Kecamatan Ciomas) dan Wanawisata Penangkaran Rusa.

Pemerintah Kabupaten Bogor terus berupaya mengembangkan potensi sumber daya pariwisata yang dimiliki sebagai salah satu destinasi wisata. Salah satu bentuk upaya Kabupaten Bogor mewujudkan visi mengembangkan destinasi wisata adalah dengan melakukan penataan pada daerah tujuan wisata utama, yaitu mina edu-wisata, dengan lingkup kecamatan Ciseeng-Gunung Sindur-Parung dan Kemang.

Berdasarkan Rencana Induk Pembangunan Kepariwisataan Kabupaten Bogor, Kawasan Minapolitan merupakan salah satu destinasi perkotaan, dengan target 


\section{National Conference of Creative Industry: \\ Sustainable Tourism Industry for Economic Development}

Universitas Bunda Mulia, Jakarta, 5-6 September 2018 e-ISSN No: 2622-7436

wisatawan menyasar pada wisatawan lokal dan sekitaran Jabodetabek yang bersifat allocentric serta wisatawan asing dari Timur Tengah dan Eropa. Kawasan Minapolitan yang berada di Kecamatan Ciseeng telah dikenal dengan sentra budidaya ikan hias. Wisata buatan yang memanfaatkan ketersediaan sumber daya alam berupa situ untuk kegiatan pembudidayaan ikan hias dan ikan konsumsi menjadi daya tarik wisata yang membedakan pasar wisata dengan destinasi wisata lain di sekitarnya. Wisatawan yang berkunjung umumnya adalah pebisnis yang datang untuk perniagaan komoditi ikan hias yang meluangkan waktu untuk mengunjungi sentra-sentra perikanan.

Hasil observasi lapangan, Kawasan Minapolitan berada dalam kawasan yang sudah berkembang namun memiliki permasalahan yang potensial untuk diselesaikan. Kota Bogor dan Kota Depok yang relatif dekat dengan Kawasan Minapolitan menjadi bagian dari destinasi para pebisnis ikan hias. Akomodasi yang lengkap dan fasilitas perkotaan lainnya yang mumpuni menjadi satu kesatuan destinasi wisata perkotaan. Dampak dari satu kesatuan destinasi perkotaan tersebut maka para wisatawan pebisnis hanya meluangkan waktu di Kawasan Minapolitan dalam waktu singkat dan sisa waktunya lebih lama dihabiskan di Kota Bogor, Depok ataupun tempat lainnya.

Dampak lain antara lain tidak optimalnya multiplier-effect dari kunjungan wisatawan pebisnis untuk pembangunan pariwisata lokal karena akomodasi di sekitar belum lengkap. Resiko kemacetan lalu lintas yang berulang karena daya tarik wisata berada di wilayah perkotaan, wisatawan cenderung akan menghabiskan waktu lebih lama apabila akomodasi di sekitar Kawasan Minapolitan cukup lengkap atau sebaliknya mungkin tidak ingin berkunjung sama sekali.

Berdasarkan data dari Dinas Pariwisata dan Kebudayaan Kabupaten Bogor dalam Masterplan Kawasan Strategis Pariwisata Minapolitan Kabupaten Bogor, definisi minawisata adalah pendekatan pengelolaan terpadu yang berbasis konservasi dengan menitikberatkan pada pengembangan perikanan dan pariwisata bahari. Namun dalam konteks perencanaan pariwisata Kabupaten Bogor, pengembangan minawisata menitikberatkan pada wisata edukasi. Diketahui bahwa Kecamatan Ciseeng merupakan kawasan yang potensial untuk dijadikan sebagai kawasan sentra minawisata, yang mana daerah ini memenuhi persyaratan ekologis, memiliki potensi perikanan serta alam dengan suasana pedesaan.

Pada penelitian ini, penulis menganalisis potensi Kawasan Minapolitan sebagai destinasi wisata dari aspek-aspek antara lain : ketersediaan daya tarik dan aktivitas wisata, industri pariwisata. Tujuan dilakukan penelitian ini adalah untuk mengetahui potensi wisata yang ada di Kawasan Minapolitan sehingga bisa dikembangkan.

Berdasarkan Undang-undang Kepariwisataan No. 10 Tahun 2009, daerah tujuan wisata atau yang dikenal dengan destinasi wisata adalah kawasan geografis yang berada dalam satu atau lebih wilayah administrattif yang didalamnya terdapat daya tarik wisata, fasilitas umum, fasilitas pariwisata, aksesibilitas, serta masyarakat yang saling terkait dan melengkapi terwujudnya kepariwisataan. Ir. FIrmansyah Rahim dalam buku yang berjudul pedoman kelompok sadar wisata, mendefinisikan wisata sebagai kegiatan perjalanan yang dilakukan oleh seseorang atau sekelompok orang dengan mengunjungi tempat tertentu untuk tujuan rekreasi, pengembangan pribadi, atau mempelajari keunikan daya tarik wisata yang dikunjungi dalam jangka waktu tertentu. Sementara itu, beliau menambahkan definisi daya tarik wisata adalah segala sesuatu yang memiliki keunikan, keindahan, dan nilai yang berupa keanekaragaman kekayaan alam, budaya, dan hasil buatan manusia yang menjadi sasaran atau tujuan kunjungan wisatawan. 


\section{National Conference of Creative Industry: \\ Sustainable Tourism Industry for Economic Development}

Universitas Bunda Mulia, Jakarta, 5-6 September 2018 e-ISSN No: 2622-7436

Sinergitas keterkaitan usaha dan kegiatan kepariwisataan akan membentuk suatu kesatuan sistem interaksi antara komponen yang satu dengan komponen lain dan merupakan suatu kegiatan yang bersifat menyatu dan menyeluruh (holistic). Komponen produk pariwisata yang diperlukan antara lain :

1. Daya tarik wisata. berupa : alam, budaya, buatan manusia atau sesuatu yang bisa dilihat oleh wisatawan (something to see), sesuatu yang bisa dilakukan (something to do), dan sesuatu yang bisa dibeli/dibawa pulang (something to buy).

2. Amenitas atau akomodasi. Berupa : fasilitas dan kelengkapan yang dapat digunakan oleh wisatawan untuk beristirahat dan bersantai dengan nyaman.

3. Aksesibilitas dan transportasi

4. Infrastruktur pendukung. Seperti : Pelabuhan udara, stasiun kereta api dan jaringan telekomunikasi, jaringan listrik, air minum, toilet dan sebagainya.

5. Fasilitas Pendukung Wisata Lainnya, seperti : keamanan, rumah makan, biro perjalanan, toko cinderamata, pusat informasi wisata, rambu wisata, fasilitas perbelanjaan, hiburan malam, fasilitas perbankan.

6. Kelembagaan dan Sumberdaya Manusia Pariwisata

Kepariwisataan sebagai industri dimaknai sebagai sebuah rangkaian proses aktivitas atau kegiatan produksi yang menghasilkan nilai tambah dan produknya bisa bersifat tidak konkrit atau kasat mata.

Ada beberapa karakteristik industri kepariwisataan yang menyebabkan industri ini mampu berperan sebagai lokomotif bagi pertumbuhan ekonomi suatu negara (Bambang Sunaryo, Kebijakan Pembangunan Destinasi Pariwisata, Konsep dan Aplikasinya di Indonesia, $2013: 35)$, yaitu :

1. Sektor kepariwisataan adalah sebuah industri yang mempunyai keterkaitan rantai nilai (multiplier effect) yang panjang dan mampu menjalin sinergi pertumbuhan dengan berbagai usaha mikro termasuk kegiatan home industry.

2. Usaha kepariwisataan mampu menyerap banyak sumberdaya setempat (local resource based) dan utamanya berbahan baku yang relative tidak pernah habis atau terbaharui (renewable resources).

3. Dalam industri kepariwisataan tidak ada over supply karena mempunyai karakteristik produk yang khas, dan relative tidak terpengaruh oleh situasi resesi/krisis ekonomi pada suatu negara.

Sementara itu, menurut Undang-undang Kepariwisataan no. 10 Tahun 2009, mendefinisikan Usaha pariwisata adalah usaha yang menyediakan barang dan/atau jasa bagi pemenuhan kebutuhan wisatawan dan penyelenggaraan pariwisata.

\section{METODE PENELITIAN}

Penelitian ini berlokasi di Kabupaten Bogor, Kawasan Minapolitan Ciseeng. Menggunakan metode deskriptif untuk menganalisis potensi Kawasan Minapolitan dilihat dari aspek-aspek antara lain : ketersediaan daya tarik dan aktivitas wisata dengan menggunakan analisis SWOT, serta menganalisis industri pariwisata berdasarkan observasi lapangan. 


\section{HASIL PENELITIAN}

Minapolitan terdiri dari kata mina dan kata politan (polis). Mina berarti perikanan dan politan berarti kota, sehingga Minapolitan diartikan sebagai kota perikanan atau kota di daerah lahan perikanan. Secara definitive Minapolitan adalah kota perikanan yang tumbuh dan berkembang karena berjalannya sistem dan usaha perikanan, serta mampu melayani dan mendorong kegiatan pembangunan perikanan di wilayah sekitarnya, dengan ciri utama kegiatan perikanan dan pengolahan hasil perikanan. Sedangkan definisi Minapolitan yang tercantum dalam Peraturan Menteri Nomor 12 Tahun 2010, adaah konsepsi pembangunan ekonomi kelautan dan perikanan berbasis kawasan berdasarkan prinsip-prinsip terintegrasi, efisiensi, berkualitas dan percepatan. Sesuai dengan KEP.39/MEN/2011 tentang Perubahan atas Keputusan MKP No. KEP.32/MEN/2010 tentang Penetapan Kawasan Minapolitan, telah ditetapkan 223 Kabupaten/Kota di wilayah Indonesia sebagai Kawasan Minapolitan.

Dalam Peraturan Daerah Kabupaten Bogor Nomor 19 Tahun 2008 tentang Rencana Tata Ruang Wilayah Kabupaten Bogor tahun 2005 - 2025, pada pasal 35 tentang kawasan perikanan dikembangkan pada wilayah/kawasan yang secara teknis, sosial, dan ekonomi memiliki potensi untuk kegiatan perikanan, kolam air tenang, air deras, pembenihan, kolam ikan hias/aquarium, dan budidaya ikan di perairan umum, 19 kawasan yang ditentukan adalah kecamatan Leuwiliang, Pamijahan, Cibungbulang, Ciampea, Dramaga, Ciomas, Kemang, Parung, Ciseeng, Cibinong, Sukaraja, Ciawi, Caringin, Cijeruk, Cigombong, Cileungsi, Jonggol, Cariu, dan Tanjungsari. Kemudian pada pasal yang sama dijelaskan bahwa pasar pengumpul dan pelelangan ikan air tawar dapat dibangun pada sentra produksi ikan di Kecamatan Cibinong, Sukaraja, dan Ciseeng.

Keterangan diatas menjelaskan bahwa Kawasan Minapolitan telah ditentukan oleh pemerintah melalui Peraturan Daerah Kabupaten Bogor Nomor 19 Tahun 2008. Namun belum berupa kawasan yang diperuntukan untuk wisata. Dari hasil penelitian di lapangan, diketahui bahwa Kawasan Minapolitan berada di tiga kecamatan, yaitu Kecamatan Ciseeng, Parung, Gunung Sindur, dan Kemang. Terdapat 13 daya tarik wisata di kawasan ini, lebih jelas dapat dilihat pada tabel di bawah :

Tabel 3.1 Daya Tarik Wisata Di Kawasan Minapolitan

\begin{tabular}{|l|l|l|}
\hline Kecamatan & Daya Tarik Wisata & $\begin{array}{l}\text { Jenis Daya Tarik Wisata } \\
\text { dan Aktivitas Wisata }\end{array}$ \\
\hline Ciseeng & Sentra Minapolitan & $\begin{array}{l}\text { Buatan Edukasi } \\
\text { Minawisata }\end{array}$ \\
\hline Ciseeng & Setu Iwul & Alam \\
\hline Ciseeng & Setu Parigi Mekar & Pemacingan \\
\hline Parung & Air Panas Tirta Sanita & Alam \\
\hline Parung & $\begin{array}{l}\text { Air Panas Gunung Hitam } \\
\text { Ciseeng }\end{array}$ & Alam \\
\hline Parung & $\begin{array}{l}\text { Air Panas Gunung Peyek } \\
\text { TTNI Nubika }\end{array}$ & Alam \\
\hline Parung & Setu Lebak Wangi Garden & Pemancingan \\
\hline Parung & Agrowisata Inagro & Edukasi pertanian \\
\hline
\end{tabular}


National Conference of Creative Industry:

Sustainable Tourism Industry for Economic Development

Universitas Bunda Mulia, Jakarta, 5-6 September 2018

e-ISSN No: 2622-7436

\begin{tabular}{|l|l|l|}
\hline Parung & Pasar Ikan Parung & Perbelanjaan ikan hias \\
\hline Parung & Sapadia Outbound & Alam - rekreasi outbound \\
\hline Gunung Sindur & Situs Batu Tapak & Budaya \\
\hline Kemang & Setu Cilala & $\begin{array}{l}\text { Alam - rekreasi edukasi } \\
\text { dan pemancingan }\end{array}$ \\
\hline Kemang & $\begin{array}{l}\text { Setu Jampang/Lengkong } \\
\text { Barang }\end{array}$ & $\begin{array}{l}\text { ALam - rekreasi edukasi } \\
\text { dan pemancingan }\end{array}$ \\
\hline Kemang & Bio Ozon & $\begin{array}{l}\text { Buatan edukasi } \\
\text { minawisata }\end{array}$ \\
\hline
\end{tabular}

Sumber : data dari Kecamatan Ciseeng, 2018

Dari hasil penelitian di lapangan, penulis menganalisis potensi wisata di Kawasan Minapolitan menggunakan analisis SWOT.

Tabel 3.2 Analisis SWOT Potensi Wisata Di Kawasan Minapolitan

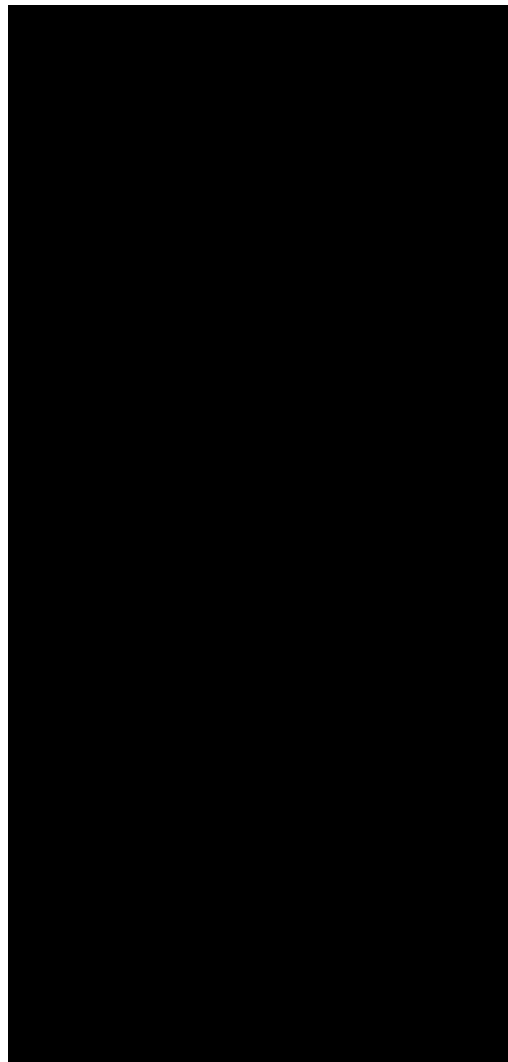

Strength (Kekuatan)

1. Tersedia daya tarik wisata

2. Jarak dengan distribusi dekat

3. Jarak daya tarik wisata satu dengan yang lain tidak terlalu jauh

4. Lingkungan yang Islami

5. Selain berpotensi sebagai kawasan Mina wisata, juga memiliki potensi wisata religi.

6. Memiliki potensi wisata untuk penelitian dan atau pembelajaran.

\section{Opportunities (Peluang)}

1. Terbuka peluang potensi daya tarik wisata lain.

2. Terbuka peluang usaha pariwisata yang lebih luas.

3. Belum adanya kompetitor.

4. Terbukanya lapangan pekerjaan yang lebih

\section{Weakness (Kelemahan)}

. Kurangnya pengetahuan sadar wisata.

2. Minimnya aksesibilitas fisik

3. Minimnya sarana dan prasarana pendukung pariwisata.

4. Kurang variasi atraksi wisata

5. Adanya pungli

\section{Strategi W-O}

1. Kerjasama antara tempat wisata yang satu dengan yang lain.

2. Kerjsama dengan travel agent

3. Memberikan pengetahuan/pelatih an kepada
1. Meningkatkan pengetahuan masyarakat akan sadar wisata.

2. Meningkatkan atraksi wisata

3. Kerjasama dengan pemerintah, investor membangun bersama sarana, prasarana dan 
luas.

5. Terbukanya kesempatan masyarakat untuk meningkatkan

pengetahuan. Contoh : belajar bahasa inggris, belajar keterampilan baru, bertemu dengan orang baru yang memiliki budaya yang berbeda dengan local.

6. Menimbulkan perasaan bangga akan daerahnya.

7. Meningkatkan perekonomian lokal

8. Memungkinkan terjadi asimilai dan akulturasi budaya

9. Terjadinya transfer nilai budaya.

\section{Threats (Ancaman)}

1. Pemahaman masyarakat untuk memanfaatkan potensi wisata belum maksimal.

2. Tenaga kerja pariwisata belum bersertifikasi

3. Pungli yang meresahkan wisatawan.

4. Belum berjalannya lembaga/organisasi sadar wisata

5. Masih rendahnya tingkat pendidikan masyarakat di sekitar kawasan.

6. Daya dukung lingkungan yang terbatas untuk akumulasi kegiatan wisata yang lebih besar sehingga berdampak pada penurunan kualitas fisik lingkungan alam dan daya tarik objek wisata. masyarakat lokal akan sadar wisata

4. Promosi

5. Harmonisasi dan registrasi bidang usaha pariwisata. aksesibilitas.

aksesibilitas. 
Berdasarkan pada hasil analisis diatas, diketahui bahwa Kawasan Minapolitan memiliki potensi yang bisa dikembangkan. Dengan adanya diferensiasi produk diharapkan dapat menjadi magnet menarik minat wisatawan untuk berkunjung. Tentunya disertai dengan peningkatan sumber daya manusia dan aksesibilitas, kunjungan wisatawan akan meningkat

Pada penelitian ini, penulis juga menganalisis dari sisi industri pariwisata di Kawasan Minapolitan. Tabel dibawah menjelaskan hasil analisis industri pariwisata di Kawasan Minapolitan yang dilakukan oleh peneliti setelah melakukan observasi lapangan.

Tabel 3.3 Analisis Industri Pariwisata Di Kawasan Pariwisata

\begin{tabular}{|c|c|}
\hline Usaha Bidang Pariwisata & Analisis \\
\hline Daya tarik wisata & $\begin{array}{l}\text { Usaha daya tarik wisata di Kawasan } \\
\text { Minapolitan sudah cukup berkembang. } \\
\text { Namun konsentrasi kunjungan wisatawan } \\
\text { masih berpusat pada kawasan wisata yang } \\
\text { dikelola oleh pihak swasta, daya tarik } \\
\text { wisata yang dikelola oleh masyarakat lokal } \\
\text { menunjukkan } \\
\text { perkembangan. }\end{array}$ \\
\hline Kawasan pariwisata & $\begin{array}{l}\text { Untuk usaha kawasan pariwisata juga } \\
\text { sudah menunjukkan perkembangan, } \\
\text { namun usaha yang yang dikelola oleh } \\
\text { masyarakat belum nenunjukkan geliat } \\
\text { usaha pariwsata. }\end{array}$ \\
\hline Jasa transportasi wisata & $\begin{array}{l}\text { Usaha jasa transpotasi wisata belum ada. } \\
\text { Wisatawan yang berkunjung umumnya } \\
\text { memakai kendaraan pribadi atau rental. }\end{array}$ \\
\hline Jasa makanan dan minuman & $\begin{array}{l}\text { Usaha jasa makanan dan minuman sudah } \\
\text { cukup berkembang di Kawasan } \\
\text { Minapolitan. }\end{array}$ \\
\hline Penyediaan akomodasi & 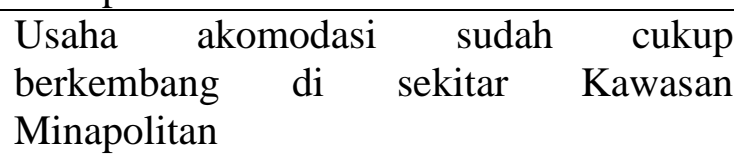 \\
\hline Penyediaan kegiatan hiburan dan rekreasi & $\begin{array}{l}\text { Penyelenggaraan kegiatan hiburan dan } \\
\text { rekreasi masih berupa kegiatan yang } \\
\text { bersifat modern, pertunjukkan tradisional } \\
\text { yang menunjukkan kearifan lokal belum } \\
\text { ada. }\end{array}$ \\
\hline Jasa informasi pariwisata & Jasa informasi pariwisata resmi belum ada. \\
\hline Wisata tirta & $\begin{array}{l}\text { Kegiatan wisata tirta sudah berkembang, } \\
\text { khususnya pemandian air panas, } \\
\text { sedangkan pemanfaatan Setu masih } \\
\text { berfokus pada perikanan dan belum } \\
\text { meiliki fasilitas maupun kegiatan wisata. }\end{array}$ \\
\hline
\end{tabular}

Sumber : hasil analisis, 2018 


\section{National Conference of Creative Industry: \\ Sustainable Tourism Industry for Economic Development}

Universitas Bunda Mulia, Jakarta, 5-6 September 2018 e-ISSN No: 2622-7436

Dari analisis di atas hasil observasi lapangan, menunjukkan bahwa industri pariwisata di Kawasan Minapolitan masih terbuka kesempatan luas untuk dikembangkan baik dari segi daya tarik wisata, kawasan pariwisata, jasa transportasi wisata, jasa makanan dan minuman, penyediaan akomodasi, penyediaan kegiatan hiburan dan rekreasi, jasa informasi wisata, hingga wisata tirta.

\section{KESIMPULAN}

Minapolitan terdiri dari kata mina dan kata politan (polis). Mina berarti perikanan dan politan berarti kota. Definisi Minapolitan yang tercantum dalam Peraturan Menteri Nomor 12 Tahun 2010, adaah konsepsi pembangunan ekonomi kelautan dan perikanan berbasis kawasan berdasarkan prinsip-prinsip terintegrasi, efisiensi, berkualitas dan percepatan. Kawasan Minapolitan berada di tiga kecamatan, yaitu Kecamatan Ciseeng, Parung, Gunung Sindur, dan Kemang dengan 14 daya tarik wisata, antara lain : sentra minapolitan, air panas Gunung Hitam Panjang, air panas Tirta Sanita, air panas Gunung Peyek, bio ozon, Situ Iwul, Situ Jampang, Setu Lengkong Barang, Setu Cilala, pasar ikan Parung, Setu Lebak Wangi, Sapadia outbound, Inagro - Agrowisata, Situs Batu Tapak Cidokom.

Berdasarkan pada hasil analisis SWOT, diketahui bahwa Kawasan Minapolitan memiliki potensi yang bisa dikembangkan. Dengan adanya diferensiasi produk dan kegiatan wisata diharapkan dapat menjadi magnet menarik minat wisatawan untuk berkunjung. Disertai dengan sumber daya manusia yang terampil dan aksesibilitas yang memadai, kiranya kunjungan wisatawan akan meningkat.

Hasil analisis di lapangan, terbuka luas kesempatan berusaha di industri pariwisata khususnya Kawasan Minapolitan baik dari segi daya tarik wisata, kawasan pariwisata, jasa transportasi wisata, jasa makanan dan minuman, penyediaan akomodasi, penyediaan kegiatan hiburan dan rekreasi, jasa informasi wisata, hingga wisata tirta.

\section{DAFTAR PUSTAKA}

Dinas Kebudayaan Dan Pariwisata Kabupaten Bogor. 2017. Masterplan Kawasan Strategis Pariwisata Minapolitan Kabupaten Bogor

Judisseno K, Rimsky. 2017. Aktivitas Dan Kompleksitas Kepariwisataan. PT. Gramedia Pustaka Utama, Jakarta

Kusmayadi \& Endar Sugiarto. 2000. Metodologi Penelitian Dalam Bidang Kepariwisataan. Jakarta

Perda Kabupaten Bogor Nomor 19 Tahun 2008 Tentang Rencana Tata RUang Wilayah Kabupaten Bogor Tahun 2005 - 2025

Rahim, Firmansyah. 2012. Buku Pedoman Kelompok Sadar Wisata. Direktorat Jenderal Pengembangan Destinasi Pariwisata - Kementrian Pariwisata dan Ekonomi Kreatif

Sekretariat Jenderal Kementrian Kelautan dan Perikanan. 2013. Pengembangan Kawasan Minapolitan. Jakarta

Sunaryo, Bambang. 2013. Kebijakan Pembangunan Destinasi Pariwisata, Konsep dan Aplikasinya di Indonesia. Gava Media : Yogyakarta 